\title{
3: $106568880-106776709$
}

National Cancer Institute

\section{Source}

National Cancer Institute. 3: 106568880-106776709. NCI Thesaurus. Code C41681.

Physical location of ALCAM_Gene 